\title{
Changes in Wettability of Heat-Treated Wood due to Artificial Weathering
}

\author{
Xianai Huang ${ }^{1}$, Duygu Kocaefe ${ }^{* 1}$, Yasar Kocaefe ${ }^{1}$, Yaman Boluk ${ }^{2}$, Andre Pichette ${ }^{1}$ \\ ${ }^{1}$ Université du Québec à Chicoutimi, Canada \\ 555, boul. de l’Université, Chicoutimi Québec Canada G7H 2B1 \\ ${ }^{2}$ University of Alberta, Canada \\ 3-142 Markin/CNRL Natural Resources Engineering Facility \\ Edmonton, Alberta, Canada T6G 2W2
}

Corresponding author:

Duygu Kocaefe

E-mail: dkocaefe@uqac.ca

Phone: 418-545 5011ext.5215

Fax: 418-545-5012

\section{Journal Name: Wood Science and Technology}

\begin{abstract}
Effect of artificial weathering on the wettability of three heat-treated North American species (jack pine, aspen, and birch) is studied from the point of view of the structural and chemical changes taking place on the wood surface. Weathering increases wettability of all three heat-treated woods by water. Changes in wettability during artificial weathering differ according to heat treatment procedure and wood species, and are likely due to combination of structural and chemical changes of the surfaces. SEM analysis indicates that cracks form due to degradation taking place during weathering. As a result, water has easier entry into the cell wall, which consequently increases wettability. IR spectra suggest that the $\mathrm{OH} / \mathrm{CH}_{2}$ ratio for heat-treated specimens is inversely proportional to the contact angle regardless of the type of wood species. The presence of cellulose-rich layer on wood surface and increasing amount of amorphous cellulose transformed from crystallized cellulose due to weathering result in increase of hydroxyl, consequently, it increases heat-treated wood wettability.
\end{abstract}




\section{Introduction and background}

Heat-treated wood is natural wood heated to temperatures of $160-230^{\circ} \mathrm{C}$, usually above $200^{\circ} \mathrm{C}$, depending on the species used and the desired material properties (Kocaefe et al. 2008b). Heat-treated woods have been used for outdoor purposes because of the new properties such as reduced hygroscopy, improved dimensional stability, better resistance to degradation by insects and micro-organisms, and attractive dark color. Wood heat treatment has widely spread in the last few years as an industrial process which is used to improve wood properties (Esteves and Pereira 2009). Decrease in hygroscopicity, improvement in dimensional stability and loss of mechanical properties of wood treated at high temperature are the focus of many early research work reported in the literature (Weiland and Guyonnet 2003; Duchez et al. 2001; Kocaefe et al. 2008c). Numerous investigations have been carried out on the resistance against fungal degradation (Weiland and Guyonnet 2003; Duchez et al. 2001; Kocaefe et al. 2008c). Heattreatment process does not require any chemical addition to modify wood. A number of studies have examined extensively the chemical transformations of high temperature treated wood (Windeisen et al. 2007; Salmén et al. 2008; Aydemir et al. 2011; Brosse et al. 2010; Tumen et al. 2010). The properties and characteristics of heat-treated wood surfaces differ strongly from those of untreated wood as a result of chemical changes during heat treatment. The heat-treated wood surface properties, such as wettability and wood color, have been extensively studied (Pavlo and Niemz 2003; Nuopponen et al. 2004; Shi et al. 2011; Li et al. 2011; Hakkou et al. 2005a; Hakkou et al. 2005b; Kocaefe et al. 2008b; Wang et al. 2007; Pétrissans et al. 2003).

In outdoor applications, wood is subjected to various environmental conditions, resulting in various modifications such as surface roughening and color changes in varying degrees (Kishino and Nakano 2004a), consequently, surface degradation. Therefore, the changes in surface properties of heat-treated wood during weathering are of significant practical concern. If heat-treated woods are to have a long service life, the weathering process must be understood and treatments to retard this degradation should be developed. Chemical and physical changes of untreated wood during weathering has been extensively studied and reported (Hon 1985; Feist and Hon 1984; Hon and Feist 1986; Hon 1981; Hon and Chang 1984). The photo degradation of wood is a surface phenomenon. It was reported that the UV radiation penetrates only $75 \mu \mathrm{m}$ below the surface whereas visible light penetrates $200 \mu \mathrm{m}$ (Hon and Ifju 1978; Hon 1981). More recent research has shown that the degradation depth is exceeds the limit of $75 \mu \mathrm{m}$ and chemical changes take place up to the depth of $900 \mu \mathrm{m}$ (Hon and Ifju 1978; Hon 1981; Horn et al. 1992; Kataoka and Kiguchi 2001; Park et al. 1996; Wang and Lin 1991). Considerable research has been carried out especially on the changes of untreated woods' surface properties such as discoloration and structure degradation during weathering by Hon and his coworkers (Hon and Minemura 1991; Hon and Feist 1986; Feist and Hon 1984). Changes in wettability and color of tropic (untreated) woods due to artificial weathering were also reported (Kishino and Nakano 2004b, a).

Wetting properties of wood is one of the surface properties that is of considerable practical and economic significance for understanding chemical and physical property changes occurring during weathering. This information also gives an idea on the different adhesion or coating characteristics required in order to retard the degradation. A number of investigations were carried out on the wettability changes of wood during heat treatment. Wettability and chemical composition of four heat-treated European wood species (pine, spruce, beech, and poplar) performed at $240^{\circ} \mathrm{C}$ were studied (Pétrissans et al. 2003; Hakkou et al. 2005a; Hakkou et al. 2005b). Effect of drying method on the surface wettability of wood strands was reported (Wang et al. 2007). Kocaefe et al. (2008) studied the effect of heat treatment on the wettability of white ash and soft maple by water. There also exists some information in the literature which discusses the changes in untreated wood wettability during weathering. The effects of aging on extracted and unextracted polar and dispersion components of the surface free energy of redwood and Douglasfir were investigated (Nguyen and Johns 1979). It was suggested that loss of surface free energy with aging is related to environmental rather than wood factors. Wettability of Western red cedar panels exposed to outdoor weathering were studied from the standpoint of wood compositional change induced by weathering (Kalnins and Feist 1993). Surface aging is a significant variable affecting the wettability and adhesion of coating on wood surface (Gindl et al. 2004). It was also reported that the effects of ultraviolet light exposure on the wetting properties of spruce and teak wood, to assess the viability of ultraviolet light irradiation as a surface pretreatment technique to activate surfaces for coating adhesion (Gindl et al. 2006). They proposed UV irradiation provided cleaning of the wood surface, consequently, the wettability and surface free energy increased significantly after a specific exposure period to UV light. Changes in wettability of tropic woods due to artificial weathering were reported (Kishino and Nakano 2004a). 
As it is explained above, various studies were carried out on the wettability of untreated and heat-treated wood, and weathering of untreated wood. To our knowledge, however, the published literature on the change in heat-treated wood wettability during weathering is still lacking.

The aim of this study is to investigate the evolution in wettability of heat-treated North American jack pine (Pinus banksiana), aspen (Populus tremuloides), and birch (Betule papyrifera) during artificial weathering.

\section{Materials and methods}

\section{Testing materials}

The following three species, one softwood and two hardwood, which are commonly used for outdoor applications in North America, were studied: jack pine (Pinus banksiana), aspen (Populus tremuloides), and birch (Betule papyrifera). Wood boards of approximately $6500 \times 200 \times 30 \mathrm{~mm}$ were heat-treated in a prototype furnace of UQAC. Table 1 shows the conditions used during the heat treatment. Then, they were subjected to artificial weathering. Untreated wood boards, kiln dried with the final moisture content of about $12 \%$, were also exposed to artificial weathering along with specimens heat-treated at high temperatures for comparison purposes. Specimens were arbitrarily selected for a complete statistical randomization. They were stored in a room at $20^{\circ} \mathrm{C}$ and $40 \%$ relative humidity (RH) until they were exposed to the artificial weathering and the characterization tests described below.

Specimens of $70 \times 65 \mathrm{~mm}$ cross-section on tangential surface (Aydemir et al.) and $20 \mathrm{~mm}$ long were cut from sapwood of heat-treated and untreated wood, and then planed to smooth surfaces. The prepared specimens of $70 \times$ $65 \times 20 \mathrm{~mm}$ were used in artificial weathering tests. All analysis tests (contact angle test, FTIR analysis and SEM evaluation) were carried out on the tangential surface (Aydemir et al.) of the wood. Specimens for surface wettability tests (contact angle measurement) were cut to $20 \times 20 \times 60 \mathrm{~mm}$ in the radial, tangential, and longitudinal directions, respectively. Those for FTIR analysis and SEM evaluation were cut to $10 \times 20 \times 20 \mathrm{~mm}$ in the radial, tangential, and longitudinal directions, respectively.

\section{Artificial weathering tests}

Artificial weathering tests were conducted at the Laval University in collaboration with FPInnovation. The samples are exposed to UV light using a commercial chamber, Atlas Material Testing Technology LLC (USA) Ci65/Ci65A Xenon Weather-Ometer. A controlled irradiance water-cooled xenon arc with a CIRA inner filter and a Soda outer filter was used as the source of radiation to simulate sunlight. Tests were performed according to Cycle 1 of Standard ASTM G155: 102 min Xenon light, 18 min light and water spray (air temperature is not controlled) without dark cycle to simulate rain in natural weathering. The black panel temperature was set up to $63 \pm 3^{\circ} \mathrm{C}$ and the irradiance level was $0.35 \mathrm{~W} / \mathrm{m}^{2}$ at $340 \mathrm{~nm}$. Heat-treated samples and untreated control samples of each species were exposed to UV light. The irradiation was interrupted after 72, 168, 336, 672, 1008, and 1512 hours of exposure and two samples for each set of experimental conditions were taken out for evaluation of properties. Thus, the values of different properties evaluated in our experiment were the average measurements of two samples.

Surface wettability tests

Wetting parameters obtained with water are significantly linked to coating adhesion (de Moura and Hernández 2005, 2006). Surface wettability experiments were performed using distilled water. Measurement of contact angle was performed at room conditions of $20^{\circ} \mathrm{C}$ and $40 \% \mathrm{RH}$. The contact angles between water and wood specimen surfaces were determined using a sessile-drop system (First Ten Angstroms FTA200 equipped with CCD camera and image analysis software). This system uses video image processing which allows the faster determination of dynamic contact angles compared to the conventional contact angle goniometry. The initial period after trigger was 0.033s and the post-trigger period multiplier was set to 1.1. A drop of test liquid with a volume of $15 \mu \mathrm{l}$ was dosed automatically by an auto-syringe and picked up by the specimen $(20 \times 20 \times 60 \mathrm{~mm})$ placed on a movable sample table. Measurement of contact angle was carried out by the sessile drop method with a view across the grain. Therefore, the wetting process parallel to the grain was investigated. Six to twelve tests were performed on two different samples for each set of experimental conditions in order to account for the non-homogeneous nature of wood. The contact angles between each droplet and specimen surface were measured both on the left side and the 
right side of the droplet and the mean contact angles were automatically calculated. Images of the drop in contact with the substrate were continuously captured at full video speed. The dynamic contact angles were determined as a function of time from the images. The mean initial contact angles and the total wetting time by water were recorded to assess wood surface wettability.

Scanning electron microscopy (SEM)

Scanning electron microscopy (SEM) analysis was used to investigate the microscopic structural changes occurring on wood surface during weathering. Small wood blocks measuring $20 \times 20 \mathrm{~mm}$ on the weathered tangential face were cut from heat-treated and untreated boards after exposure to UV irradiation for different times $(0,336,672$, and 1512 hours). For subsurface cell degradation analysis, same blocks measuring $20 \times 10 \mathrm{~mm}$ on the transverse face and radial face were used. The specimens were immerged in water for 30 minutes and then cut with a razor blade mounted onto a microtome by carefully cutting one of the end-grain surfaces and one radial surface. A new razor blade should be used for each final cut. Another method is to split these surfaces; however, they are rough and usually they do not allow observation into the cell lumen. The specimens were washed in distilled water and then air-dried at room temperature more than two nights and desiccated with phosphorus pentoxide for ten days. Finally all blocks were sputter coated with a palladium/gold layer $(20 \mathrm{~nm})$ and then mounted onto standard aluminum stubs using electrically conducting paste. The samples were scanned in a Jeol scanning electron microscope (JSM $6480 \mathrm{LV}$ ) with magnification up to $300000 \times$ at $10 \mathrm{kV}$ of accelerating voltage. The distance between sample and electron microscope head was $20-25 \mathrm{~mm}$ with spot size of 35 . The specimen temperature was approximately $20^{\circ} \mathrm{C}$ and the column vacuum was $6.66 \times 10^{4} \mathrm{~Pa}$. Digital images were transferred to a personal computer and saved as image files. To improve image quality, resolution, contrast and brightness were corrected digitally on the computer. Electron micrographs were taken for UV irradiated longitudinal tangential surface for different artificial weathering times. SEM micrographs of longitudinal radial surface were also taken in order to observe the cell damage in radial direction. The maximum depth of damage was measured from each transverse SEM image.

FTIR analysis

The effect of weathering on cellulose crystallinity and the chemical compositions of both cellulose and lignin on wood surface were studied using Fourier transform infrared spectroscopy. The air-dried specimens $(10 \times 20 \times 20 \mathrm{~mm})$ were analyzed using Jasco FT/IR 4200 equipped with a diamond micro-ATR crystal. IR spectra were recorded in the wave number range of $550-4000 \mathrm{~cm}^{-1}$ at $4 \mathrm{~cm}^{-1}$ resolution for 20 scans prior to the Fourier transformation. As it was stated in introduction, the weathering degradation affects a depth of $75 \mu \mathrm{m}$ to $900 \mu \mathrm{m}$ of wood surface. The sampling depth of infrared radiation was of $0.2-5 \mu \mathrm{m}$ depending on the wave number with the micro-ATR crystal incident angle of $47^{\circ}$. This ensured that the recorded IR spectra of wood surfaces were sufficiently surface sensitive. Thus, changes in IR spectral features were solely caused by changes in surface chemistry during weathering duration, and there was no change in bulk chemistry of the interior part of wood specimen. The aperture diameter was $7.1 \mathrm{~mm}$. All spectra were analyzed using Jasco spectra manager software. The IR spectra for each treatment and artificial weathering time were transformed into absorbance spectra. All relative intensity ratios were normalized relative to the peak of the band at $2900 \mathrm{~cm}^{-1}$ which is C-H stretching in methyl and methylene groups (Kishino and Nakano 2004a). In FTIR, it is very important to use a spectral band that does not change during the treatment process if quantitative analysis is to be performed. And it is difficult to identify a reference spectral band that remains completely invariable throughout the whole treatment. The band of $2900 \mathrm{~cm}^{-1}$ is one of the bands that change less than $\mathrm{C}-\mathrm{OH}, \mathrm{C}-\mathrm{OC}$, R-COO-R OR Ar- $\mathrm{OCH}_{3}$ bonds during the treatment. This band was assumed to be invariable during experiment. In reality, it does not remain fully unchanged because it is present in volatile components, such as hydrocarbons, fatty acids, steroids, lactones, furans terpenes, etc. These volatiles leave wood surface and are partially replaced by those migrating toward surface from the interior of wood substance during treatment (Kocaefe et al. 2008a). But the chosen band is one of the bands that changes least during the treatment. The quantitative FTIR values that are used here serve only for qualitative comparison in the discussion of the results.

\section{Results and discussion}

\section{Surface wettability changes}

The dynamic wettability of wood samples which are exposed to artificial weathering for different times is recorded. This information is useful in understanding the weathering mechanism of heat-treated wood. During this study, the 
effect of the weathering on dynamic contact angle, initial contact angle and total wetting time with water, consequently, on the wetting properties of three heat-treated woods is investigated. Furthermore, the effects of heat treatment and type of wood species on the wettability were also studied.

Figures 1 presents dynamic contact angle of water as a function of time for heat-treated jack pine, aspen, and birch tangential surfaces, respectively. In these figures, the contact angle evolution with time is given for an unweathered specimen ( $0 \mathrm{~h}$ ) as well as for specimens after artificial weathering for different times (72 h, $168 \mathrm{~h}, 336 \mathrm{~h}, 672 \mathrm{~h}, 1008$ $\mathrm{h}$, and $1512 \mathrm{~h}$ ). As can be seen in the all three figures, the weathering reduces the hydrophobic behavior of these three heat-treated woods; consequently, all the contact angles of weathered heat-treated wood are lower than those of unweathered wood of the same species $(0 \mathrm{~h})$. This shows that the artificial weathering increases the wettability of wood by water. The contact angles decrease significantly after weathering of $72 \mathrm{~h}$ for all the three species at different extents depending on the species. As shown in Figure 1 (a), the contact angles of heat-treated jack pine do not seem to differ significantly after weathering for $72 \mathrm{~h}$ and $168 \mathrm{~h}$, whereas at longer times they continue to decrease with the increasing weathering times. The trends observed for both hardwood species (aspen and birch) studied are found to be very similar (see Fig. 1 (b) and (c)). Contact angles of heat-treated aspen and birch after weathering reduce with increasing weathering time.

Figure 2 shows the variation in initial contact angle with the weathering time for each species with and without heat treatment. The initial contact angles of all heat-treated and untreated specimens with the exception of untreated aspen and birch decrease with increasing exposure time during weathering. Those of untreated aspen and birch increase with artificial weathering time up to $72 \mathrm{~h}$, above this time they again decrease. This result is similar to that reported in literature (Kishino and Nakano 2004a). The initial contact angles of heat-treated specimens before artificial weathering are higher than those of untreated wood for all the three species which is in agreement with literature (Kocaefe et al. 2008b; Pétrissans et al. 2003; Hakkou et al. 2005a). However, after artificial weathering for $1008 \mathrm{~h}$, the initial contact angle of heat-treated jack pine becomes smaller than that of untreated jack pine, while same trend is observed for aspen and birch only after $72 \mathrm{~h}$ of weathering. After artificial weathering for $1512 \mathrm{~h}$, the difference between the initial contact angles of untreated and heat-treated specimens is largest for jack pine. Untreated jack pine has a contact angle of $40.3^{\circ}$, while other specimens exhibit a contact angle of less than $20.9^{\circ}$ for the same weathering time. The effect of heat treatment on initial contact angle after weathering for $72 \mathrm{~h}$ to $1008 \mathrm{~h}$ is the largest for aspen. These results show that the changes in wettability during artificial weathering differ according to heat treatment and type of wood species.

The times observed for complete surface wetting of all three species (heat-treated and untreated) by water before and after $1512 \mathrm{~h}$ of artificial weathering are presented in Table 2 . The specimens before weathering $(0 \mathrm{~h})$ exhibit different total wetting times depending on the species and whether they are heat-treated or not, ranging from $235.43 \mathrm{~s}$ for untreated aspen to $3003.73 \mathrm{~s}$ for heat-treated jack pine. The total wetting times of all specimens after weathering of $1512 \mathrm{~h}$ are less than 3.39s. This result suggests that weathering accelerates significantly absorption and penetration of water on both heat-treated and untreated wood surfaces; consequently, it reduces significantly total wetting time.

As it was stated before, weathering changes wood structural properties (Hon and Feist 1986; Miniutti 1964, 1967; Miniutti 1973; Hon 1984; Evans 1989; Paajanen 1994; Evans et al. 1996). The difference in wood surface structure can cause wettability differences of wood surfaces (Kishino and Nakano 2004a; Patton 1970). Weathering induces changes not only in physical properties of a wood surface but also in its chemical properties (Kataoka and Kiguchi 2001; Horn et al. 1992). The changes in wettability during weathering can also be related to changes in the chemical properties of a wood surface (Kalnins and Feist 1993; Gindl et al. 2004; Kishino and Nakano 2004a). As described in the introduction, heat treatment can cause chemical changes such as hemicelluloses degradation on wood surface, consequently, result in an increase in its wettability (Kocaefe et al. 2008b).

\section{Surface structural changes (SEM observations)}

SEM analysis of untreated and heat-treated specimens indicates that anatomical structure of wood is only slightly affected during heat treatment. Fibers and rays are still obvious after heat treatment. Previous research reported that the main differences were the presence of important quantities of extractives deposited in the resins channels, which disappeared after thermal treatment (Mburu et al. 2007). This implies that the structural factors do not play an important role on wettability during heat treatment. The comparison of heat-treated wood surfaces before weathering 
reveals the differences in structure for all three species (see Fig. 3 (b), (e) and (h)). The structure of jack pine (softwood) is relatively simple. The axial system is composed mostly of axial tracheids and the radial system is composed mostly of ray parenchyma cells. The structures of aspen and birch, which are hardwoods, are much more complicated than that of jack pine. Their axial systems are composed of vessel elements, fibers and axial parenchyma cells in different patterns and abundance. The presence of vessel elements is the unique feature that separates hardwoods from softwoods, which are for water conduction. Fibers in hardwoods function solely as support. Similar to jack pine, the radial system of aspen and birch is composed of ray parenchyma cells, but unlike softwoods, their rays are much more diverse in size and shape. On the longitudinal tangential section, vessels appear as large cracks. Water in contact with wood surfaces is able to penetrate into the wood substance in three ways: as liquid water flow into cell lumena by capillarity; as water vapour by diffusion into cell lumena; as bound water by diffusion within the cell wall (Banks 1973). Therefore, structural differences in surfaces could exert an influence on the water entrance into wood specimens before weathering. The existence of large cracks of vessels on the surface can be observed in aspen and birch which results in lower contact angles than those of jack pine (see Fig. 1). This result is in agreement with a previous study (Kishino and Nakano 2004a). The structural comparison of both hardwood surfaces, aspen and birch, reveals the reason for difference in their wettability. The main cells (fibers) of aspen are thinner than those of birch, which results in larger lumen volume and decrease in specific gravity. Consequently, water enters the cell wall of aspen at a faster rate; therefore, aspen has smaller contact angles (less wettable and slower water penetration) than birch (shown in Fig. 1 (b) and (c)).

SEM analysis suggests that the changes occurring due to weathering in the wettability of heat-treated woods tested in this study might be attributed to the structural changes of wood surface. Large longitudinal and horizontal cracks present on all three heat-treated species longitudinal tangential surfaces after artificial weathering for $1512 \mathrm{~h}$ allow easier entrance of water into cell wall, which consequently decreases contact angles (increases wood wettability). The structural differences in surfaces can also influence the contact angles of specimens after weathering. The longitudinal cracks of heat-treated jack pine, originated from radial ray parenchyma cells during artificial weathering produce slightly higher contact angles (see Fig. 1). In contrast, the large cracks observed on aspen and birch surfaces, originated from vessel elements due to weathering, result in lower contact angles after artificial weathering for all times. However, the contact angles of the three heat-treated woods after weathering for $1512 \mathrm{~h}$ are almost the same, which indicates the structural differences on different heat-treated species surfaces at this weathering stage does not have any significant effect on wettability.

Figure 3 shows the surface micrographs on transverse surface of untreated woods before artificial weathering, heattreated woods before and after artificial weathering for $1512 \mathrm{~h}$. Figure 4 shows the influence of maximum damage depth on the contact angles of the specimens before and after artificial weathering for $72 \mathrm{~h}, 672 \mathrm{~h}$, and $1512 \mathrm{~h}$. Comparing Figures 3(a) and (b), it can be seen that the cracks on middle lamella and slight thinning of cell wall take place on jack pine transverse surface after thermal treatment. These checks appear to be a result of a stress caused by differential shrinkage due to heat treatment. Heat-treated jack pine wood looks more brittle than its untreated counterpart. However, structural changes due to heat treatment are not distinct, and it is likely that plasticization of cell wall material occurs only to a limited degree during heat treatment. This is in agreement with the result of Kollmann and Sachs who found comparable features in spruce after thermal treatment between $190^{\circ} \mathrm{C}$ and $240^{\circ} \mathrm{C}$ (Boonstra et al. 2006). Compared to jack pine wood, aspen wood displays less structural changes due to heat treatment as presented in Figure 3 (e), showing presence of smaller cracks on cell wall and slighter thinning of cell wall width. Similar to jack pine wood, the presence of small cracks on middle lamella, slight thinning cell wall width as well as plasticization for birch takes place after heat treatment (Fig. 3(h)). The structural changes, such as cracks on cell wall and middle lamella and the thinning of cell wall should boost wood wettability. However, as stated above, the wettabilty of heat-treated wood reduces due to heat treatment for all the three species. This suggests that the chemical changes of wood surfaces have more significant effect on the wettability changes than that of structural changes during heat treatment. This supports the idea described in the previous section. Figures 3 (c), (f) and (i) show the microstructural changes of cell occurring after artificial weathering for $1512 \mathrm{~h}$ on transverse surfaces of heat-treated jack pine, aspen, and birch, respectively. The development of cracks on middles lamella and thinning of cell wall width for all of the specimens are observed (Fig. 3); however, their magnitude which is different for different species is difficult to differentiate after the weathering of $1512 \mathrm{~h}$. The differences in contact angles of different species are small after weathering for $1512 \mathrm{~h}$. This can be due to the fact that the differences in microstructure between different species are no longer significant at this stage of weathering. Because the lignin concentration is higher in the middle lamella than in the cell wall, the weather degradation occurs preferentially in 
this area of wood surface. This is noticeable in Figures 3 (c), (f), and (i). The loss of lignin makes the surface more hydrophilic; that is, contact angles decrease as shown in Figures 1 and 2.

The damaged wood layer has different physical and chemical characteristics than those of wood bulk. As shown in Figure 4, the contact angles of the specimens clearly decrease with increasing maximum damage depth for all the heat-treated wood species and their decreasing rates differ according to species type during artificial weathering. Thus, the maximum damage depth seems to play an important role in wettability of the species during artificial weathering. After weathering for the same time, the maximum damage depth on heat-treated aspen is the highest. However, the maximum damage depth effect is more significant on the initial contact angle of heat-treated aspen than those of heat-treated jack pine and birch. This result means that the change of heat-treated wood surface structure is just one of the reasons responsible for the changes in wettabiltiy due to weathering.

\section{Surface chemical changes (FTIR analysis)}

The most representative bands studied within the spectral range of $4000-550 \mathrm{~cm}^{-1}$ are summarized in Table 3 . Figure 5 shows the FTIR spectra between the spectral region of $1800-800 \mathrm{~cm}^{-1}$ on heat-treated and untreated jack pine, aspen, and birch before weathering, respectively. Differences due to species and heat treatment can be clearly seen in the infrared spectra in the band shapes.

It is found that there are significant differences at $1260 \mathrm{~cm}^{-1}$ and $1230 \mathrm{~cm}^{-1}$ between hardwood (aspen and birch) and softwood (jack pine). A doublet can be detected at $1260-1230 \mathrm{~cm}^{-1}$ in heat-treated and untreated jack pine, while only one band at $1230 \mathrm{~cm}^{-1}$ can be found in the aspen and birch spectra. This is attributable to the difference in the guaiacyl content in lignin of jack pine (softwood), aspen and birch (hardwood). The lignin of softwood (jack pine) consists of guaiacyl nuclei, while those of hardwoods (aspen and birch) are components of guaiacyl and syringyl nuclei (Colom et al. 2003). The band at $1260 \mathrm{~cm}^{-1}$ represents guaiacyl ring breathing with CO-stretching in lignin and hemicelluloses, is higher in jack pine than in aspen and birch. It can be observed that the intensity of the band at $1740 \mathrm{~cm}^{-1}$ is slightly higher in aspen and birch than in jack pine for both heat-treated and untreated woods. Colom et al. (2003) interpreted that this is probably caused by more acetyl groups of hardwood than softwood. The intensity at 1600 and $1510 \mathrm{~cm}^{-1}$ of aspen and birch are similar, while in jack pine spectra the band at $1510 \mathrm{~cm}^{-1}$ is stronger than at $1600 \mathrm{~cm}^{-1}$, which is attributable to a stronger guaiacyl element than syringyl at $1510 \mathrm{~cm}^{-1}$. This result is similar to that reported by Colom et al. (2003).

The spectra differences between heat-treated and untreated woods have to be taken into consideration. Upon analysis of the spectra, it can be seen that the band at $1510 \mathrm{~cm}^{-1}$ which is assigned to lignin increases slightly after heat treatment for all species. This peak indicates splitting of the aliphatic side chains in lignin and cross-linking formation by condensation reactions of lignin, which can decrease the water absorption and consequently increase wood dimensional stability (Kocaefe et al. 2008a). Another peak which has to be taken into consideration is the increase in C-O peak at $1103 \mathrm{~cm}^{-1}$ after heat treatment. This might suggest that the formation of new alcohols and esters, which can reduce the number of the free hydroxyl groups, increases hydrophobic character of wood (Kocaefe et al. 2008a; Colom et al. 2003).

Figures 6 (a-c) show the FTIR spectra in the spectral regions of heat-treated jack pine, aspen, and birch during artificial weathering, respectively. The overall IR spectrum of three heat-treated species indicate that a number of spectral features appear to be sensitive to weathering. As stated in Table 3, all the bands at $1600 \mathrm{~cm}^{-1}, 1510 \mathrm{~cm}^{-1}$, $1465 \mathrm{~cm}^{-1}, 1263 \mathrm{~cm}^{-1}$, and $1103 \mathrm{~cm}^{-1}$ represent lignin characteristics. As shown in Figures 6 (a-c), all these characteristic bands of lignin decrease significantly as a result of weathering process for all species. It indicates lignin is the component of heat-treated wood which is most degraded during weathering.

Out of the five bands mentioned above, the evolution of lignin loss is best explained by the peak at $1510 \mathrm{~cm}^{-1}$ of wood samples (Colom et al. 2003). Figure 7 shows the lignin loss for heat-treated and untreated wood specimens for three species after artificial weathering at different times. Before weathering, heat-treated wood surfaces show higher lignin content than those of untreated wood surfaces for the same species. After artificial weathering of $72 \mathrm{~h}$, lignin in all specimens becomes degraded although a large difference can be seen in the evolution of the degradation process. It is worth noting that the difference in lignin content between heat-treated and untreated wood reduces after weathering for $1512 \mathrm{~h}$. All of the cell wall polymers such as cellulose, hemicelluloses, and lignin are 
hydroscopic. The order of hydroscopicity is: hemicellulose (HEMI) > cellulose > lignin (KLIG) (Skaar 1984). Thus, the loss of lignin can increase the content of other components and consequently make the surface more hydrophilic. The same observation is reported by Kalnins and Feist (1993). They reported that contact angle measurements on weathered western red cedar dropped from $77^{\circ}$ to $55^{\circ}$ after four weeks of outdoor weathering. It is also reported that wettability for Sitka spruce increased when exposed to xenon arc radiation and water spray (Kang et al. 2002).

The Total Crystallinity Index $\left(\mathrm{H}_{1370} / \mathrm{H}_{2900}\right)$ is determined from the absorption ratios (Nelson and O'Connor 1964) and plotted in Figure 8 for both heat-treated and untreated specimens of three species. The values of Total Crystallinity Index refer to sum of cellulose I and cellulose $\Pi$ values (Colom et al. 2003). The results indicate that crystalline cellulose becomes degraded which cause a decrease in the crystallinity of all specimens and degradation occurs at different extents depending on species and heat treatment.

The effect of wood crystallinity on initial contact angle of heat-treated wood surfaces is shown in Figure 9. For all three species, the contact angle increases as the Total Crystallinity Index increases. This indicates the loss of crystallinity as a result of weathering which, in turn, can increase wood wettability. Water in contact with wood surfaces is able to penetrate into the wood substance in different ways (Banks 1973). A model called "zipper" describing the movement of water into the wood structure by forcing cell wall polymers (hemicellulose, cellulose, and lignin) apart as it moves deeper into the wood structure was proposed (Caulfield 1978). Therefore, differences in quantity and property of cell wall polymers in surfaces could exert an influence on the contact angles of specimens. The sorption of water by wood depends on the hydrophilic nature of each cell wall polymer as well as the accessibility of water to the hydroxyl groups of polymer. Most of the hydroxyl sites in the hemicelluloses and lignin are accessible to moisture. The non-crystalline portion (amorphous cellulose component) of cellulose, which is approximately $40 \%$, and the surfaces of the crystallites are accessible to moisture, but the crystalline part (approximately 60\%) is not (Stamm 1964; Sumi et al. 1964). The loss of crystallinity during weathering raises the amorphous cellulose component proportion and, consequently, increases the affinity for water.

Wood is a hydroscopic resource. Other than structural aspect, the functional groups such as hydroxyl groups (-OH), hydrocarbon chains $\left(-\mathrm{CH}_{2}-\right)$ and carboxyl groups $(-\mathrm{COOH})$ contribute to the affinity for water (Kishino and Nakano 2004a). The hydroxyl and carboxyl groups are hydrophilic groups, while the hydrocarbon chains are hydrophobic groups. The changes of these functional groups can change the wettabilty of water. The bands at 3500, 2900, and $1740 \mathrm{~cm}^{-1}$ in Figure 6 refer to hydroxyl groups $(-\mathrm{OH})$, hydrocarbon chains $\left(-\mathrm{CH}_{2}-\right)$ and unconjugated carbonyl groups $(\mathrm{C}=\mathrm{O})$, respectively (Tolvaj and Faix 1995; Kishino and Nakano 2004a).

Figure 10 (a) and (b) shows the $\mathrm{C}=\mathrm{O} / \mathrm{CH}_{2}$ ratio and $\mathrm{OH} / \mathrm{CH}_{2}$ ratio of heat-treated and untreated jack pine, aspen, and birch before and after weathering for $72 \mathrm{~h}$ and $1512 \mathrm{~h}$, respectively. With the exception of heat-treated and untreated birch, the $\mathrm{C}=\mathrm{O} / \mathrm{CH}_{2}$ ratios of other specimens increase up to $72 \mathrm{~h}$ and then decrease after weathering for $1512 \mathrm{~h}$ (see Fig. 10 (a)). Since the decrease in contact angle means increase in wettability, if the functional group is responsible for the increase of wettability, the tendency of the functional ratio is expected to increase with the increasing weathering time. Thus, the tendency shown in Figure 10 (a) suggests that, except heat-treated and untreated jack pine and aspen at the artificial weathering of $72 \mathrm{~h}$, the affinities of other specimens studied during the present work for water are not attributed to the carbonyl groups. Similar result was reported in the literature (Kishino and Nakano 2004a).

On the other hand, the $\mathrm{OH} / \mathrm{CH}_{2}$ ratios of all heat-treated woods increase as weathering time increases up to $1512 \mathrm{~h}$ while those of untreated woods increase relatively fast up to weathering time of $72 \mathrm{~h}$ and then decrease slightly (birch, jack pine) or stay almost constant (aspen) between $72 \mathrm{~h}$ and $1512 \mathrm{~h}$ as shown in Figure 10 (b). Before weathering, there are more hydroxyl groups on untreated wood surfaces than those of heat-treated wood for all three species; however, after weathering for $1512 \mathrm{~h}$ the opposite is true. This might explain why heat-treated woods exhibit higher wettability by water than untreated woods for all specimens after the artificial weathering process, as shown in Figure 2. It is noteworthy to mention that the presence of extractives also has a significant effect on the water wettability of heat-treated wood surface. Kalnins and Feist (1993) proposed that one reason for the wettability increase with weathering might be the reduction or removal of the water repellent effect of extractives. Extractives leave wood surface, but they are partially replaced by those migrating towards the surface from the interior of wood substance during artificial weathering exposure. Since certain extractive content has been removed during heat treatment process, extractive content of heat- treated woods is less than that of untreated woods. Therefore, 
extractives replaced by those migrating towards surface from the interior part of the untreated wood are more significant than those of heat-treated wood during weathering. Thus, the quantity of extractives present on heattreated wood surfaces is less than that of untreated wood surfaces of the same species after weathering. This decreases the hydrophobicity of heat-treated wood surfaces; consequently, decreases the contact angles (more wettable) as shown in Figure 2.

The $\mathrm{OH} / \mathrm{CH}_{2}$ ratio for each heat-treated wood species is inversely proportional to the contact angle, as shown in Figure 11. In addition, as the weathering exposure time increases, the contact angle vs. $\mathrm{OH} / \mathrm{CH}_{2}$ line shifts downwards regardless of the wood species (broken line). This indicates the $\mathrm{OH} / \mathrm{CH}_{2}$ ratio has more significant effect on surface contact angle than that of wood species type during artificial weathering. All specimens tend to exhibit the contact angles of less than $20^{\circ}$ when the $\mathrm{OH} / \mathrm{CH}_{2}$ ratios are more than 3 after weathering of $1512 \mathrm{~h}$. As described above, all characteristic IR spectra bands which represent lignin component for all three heat-treated wood species decrease during weathering. This indicates that hydrophobic lignin is degraded more than other hydrophilic wood polymers (hemicelluloses and cellulose) for the specimens tested in this study. Consequently, weathering allows cellulose to become more abundant on the surface, in other words, the wood surfaces have a cellulose-rich layer as a result of weathering. This cellulose-rich layer causes an increase in hydroxyl groups. It was proposed that a leached and eroded cellulose-rich layer remains on the wood surface after weathering (Feist and Hon 1984). The observation of cellulose-rich layer on tropic wood surfaces after artificial weathering has been reported by Kishino and Nakano (2004a). The band at $3500 \mathrm{~cm}^{-1}$ assigns hydroxyl groups from water and three wood polymer components contain (lignin, cellulose, and hemicelluloses) (Kocaefe et al. 2008b). This is confirmed by the $\mathrm{OH} / \mathrm{CH}_{2}$ ratios calculated by IR intensity of band at $3500 \mathrm{~cm}^{-1}$ to band at $2900 \mathrm{~cm}^{-1}$ for all specimens tested during this study, which are more than that of oven-dried filter paper (1.7) (Kishino and Nakano 2004a). In view of the literature and the study stated above, it can be expected that the hydroxyl groups originate not only from cellulose exposed to artificial weathering, but also from other polymers (such as hemicelluloses) and the adsorbed water; and this increases wettability of heattreated wood. It is worth to note that part of increase in wettability on heat-treated wood surface due to weathering can be attributed to the increase of the free hydroxyl groups on surface. During this study, it is shown that the crystallinity of cellulose decreases as a function of weathering exposure. That means the cellulose component that originates from crystallized cellulose is affected, which consequently allows more amorphous cellulose content to form during the degradation process. The amorphous cellulose component exhibits additional free hydroxyl groups in the cell wall than crystallized cellulose, which can form more hydrogen bonds with environmental moisture and increase water absorption.

Moreover, the results shown in Figure 11 indicates that the heat-treated specimens tend to exhibit approximately constant initial contact angle of around $15^{\circ}$ (see Fig. 2) for different $\mathrm{OH} / \mathrm{CH} 2$ ratios depending on the species after artificial weathering for $1512 \mathrm{~h}$. This means that the contact angle of the specimen at this stage is independent of the parameters measured $\left(\mathrm{OH} / \mathrm{CH}_{2}\right.$ ratios) in this study. This result agrees with the finding by Kalnins and Feist (1993) stating that differences between species are probably no longer significant at this stage in regard to wettability. However, differences between species still exist even after the surface develops a cellulose-rich layer with regard to chemical properties. This result is in accordance with that found by Kishino and Nakano (2004a). They reported that the wood specimens exhibit a contact angle of $0^{\circ}$ at $10 \mathrm{~s}$ for different $\mathrm{OH} / \mathrm{CH}_{2}$ ratios after artificial weathering of $600 \mathrm{~h}$ depending on the species type. On the other hand, the initial contact angles for the heat-treated specimens before weathering $(0 \mathrm{~h})$ and after weathering for $72 \mathrm{~h}$ decrease as $\mathrm{OH} / \mathrm{CH}_{2}$ ratios increase depending on different species (Fig. 11). This result conflicts with the statement by Kishino and Nakano (2004a) who found that the $\mathrm{OH} / \mathrm{CH}_{2}$ ratios for the specimens before weathering were approximately constant regardless of the contact angle. The influence of $\mathrm{OH} / \mathrm{CH}_{2}$ ratios of different species on initial contact angle at different weathering times (such as 0 h, $72 \mathrm{~h}$, and $1512 \mathrm{~h}$ ) is different. Parallel to these results, the contact angle is found to be dependent on $\mathrm{OH} / \mathrm{CH}_{2}$ ratios at different extents depending on weathering time for the heat-treated specimens tested in this study. Thus, it is probable that factors other than chemical properties, for example structural factors stated above, affect the differences in contact angles of the specimens during different weathering stages.

The presence of extractives also has a great effect on the weathering of wood for water and other liquids. Two types of extractives were discussed in wood: extractives deposited in the coarse capillary structure and extractives deposited in the cell wall structure(Stamm and Loughborough 1942). The extractives deposited in the cell wall structure have a great influence on the rate of swelling. As wood is exposed to weathering, the extractives are 
leached from the surfaces and the surface becomes less water-repellent (Kalnins and Feist 1993). The role of extractives in heat-treated wood during weathering process needs to be investigated further.

\section{Conclusions}

The weathering increases the wettability of all three heat-treated woods by water. Weathering accelerates significantly absorption and penetration of water on both heat-treated and untreated wood surfaces; consequently, it reduces significantly total wetting time. Changes in wettability during artificial weathering depend on the nature of the heat treatment process and type of wood species.

SEM analysis indicates that the role of structural factors does not seem to be significant on the wettability change observed during heat treatment. Cracks due to weathering degradation result in easier entrance of water into cell wall of heat-treated wood, which consequently increases wood wettability. Weather degradation occurs preferentially in middle lamella of wood surface, where the lignin concentration is higher than that in the cell wall. Contact angles of the specimens clearly decrease with increasing the maximum damage depth for all the heat-treated wood species and their rates of decrease differ according to species type during weathering. Structural differences in different species surfaces could have an influence on the water entry into the wood before weathering. The differences in contact angles of different species after weathering for $1512 \mathrm{~h}$ are not significant which indicates differences in microstructures of different species are no longer significant at this stage of weathering.

The IR spectra suggest that the $\mathrm{OH} / \mathrm{CH}_{2}$ ratio for heat-treated specimens is inversely proportional to the contact angle regardless of the wood species. Lignin is more sensitive to the degradation process than other wood polymers and the weathering degrades the hydrophobic lignin component of lignin more than others for specimens tested in this study. Consequently, weathering allows cellulose to become more abundant on the surface. The cellulose-rich layer on wood surface causes the increase in hydroxyl groups. The increasing amorphous cellulose transformed from crystallized cellulose due to weathering increases free hydroxyl groups, which is another reason of wettability increase.

From this analysis, the changes in wettability during weathering are estimated to be due to the combination of structural changes in surfaces and chemical changes.

\section{Acknowledgments}

The authors thank Fonds québécois de la recherche sur la nature et les technologies (FQRNT), Développement Économique Canada (DEC), Ministère du Développement Économique, de l'Innovation et de l'Exportation (MDEIE), Conférence Régionale des Élus du Saguenay-Lac-St-Jean (CRÉ), Université du Québec à Chicoutimi (UQAC), Fondation de l'Université du Québec à Chicoutimi (FUQAC), FPInnovation, Alberta Innovates, and industrial partners (PCI Ind., Ohlin Thermotech, Kisis Technology, and Industries ISA) for their technical and financial contributions as well as Centre universitaire de recherche sur l'aluminium (CURAL) for valuable assistance and technical support during SEM tests.

\section{References}

Aydemir D, Gunduz G, Altuntaş E, Ertas M, Turgut Şahin H, Hakki Alma M (2011) Investigating changes in the chemical constituents and dimensional stability of heat-treated hornbeam and uludag fir wood. BioResources 6 (2):1308-1321

Banks WB (1973) Water uptake by scots pine sapwood, and its restriction by the use of water repellents. Wood Science and Technology 7 (4):271-284. doi:10.1007/bf00351073

Boonstra MJ, Rijsdijk JF, Sander C, Kegel E, Tjeerdsma B, Militz H, Van Acker J, Stevens M (2006) Microstructural and physical aspects of heat treated wood. Part 1. Softwoods. Maderas: Ciencia y Tecnologia 8 (3):193-208 
Brosse N, El Hage R, Chaouch M, Pétrissans M, Dumarçay S, Gérardin P (2010) Investigation of the chemical modifications of beech wood lignin during heat treatment. Polymer Degradation and Stability 95 (9):17211726. doi:10.1016/j.polymdegradstab.2010.05.018

Caulfield DF (1978) The effect of cellulose on the structure of water. Fiber-water Interactions in Paper-making:63

Colom X, Carrillo F, Nogués F, Garriga P (2003) Structural analysis of photodegraded wood by means of FTIR spectroscopy. Polymer Degradation and Stability 80 (3):543-549

de Moura LF, Hernández RE (2005) Evaluation of varnish coating performance for two surfacing methods on sugar maple wood. Wood and Fiber Science 37 (2):355-366

De Moura LF, Hernández RE (2006) Effects of abrasive mineral, grit size and feed speed on the quality of sanded surfaces of sugar maple wood. Wood Science and Technology 40 (6):517-530

Duchez L, Herri JM, Guyonnet R (2001) Modelling of a Wood Retification Furnace, Proceedings of 8th Francophone Congres in Process Engineering:61-68

Esteves BM, Pereira HM (2009) Wood modification by heat treatment: A review. BioResources 4 (1):370-404

Evans PD (1989) Structural changes in Pinus radiata during weathering. J Inst Wood Sci 11 (5):172-181

Evans PD, Thay PD, Schmalzl KJ (1996) Degradation of wood surfaces during natural weathering. Effects on lignin and cellulose and on the adhesion of acrylic latex primers. Wood Science and Technology 30 (6):411-422

Feist WC, Hon DNS (1984) Chemistry of Weathering and Protection. The Chemistry of Solid Wood, Ed

Gindl M, Reiterer A, Sinn G, Stanzl-Tschegg SE (2004) Effects of surface ageing on wettability, surface chemistry, and adhesion of wood. Holz als Roh - und Werkstoff 62 (4):273-280

Gindl M, Sinn G, Stanzl-Tschegg SE (2006) The effects of ultraviolet light exposure on the wetting properties of wood. Journal of Adhesion Science and Technology 20 (8):817-828

Hakkou M, Pétrissans M, El Bakali I, Gérardin P, Zoulalian A (2005a) Wettability changes and mass loss during heat treatment of wood. Holzforschung 59 (1):35-37

Hakkou M, Pétrissans M, Zoulalian A, Gerardin P (2005b) Investigation of wood wettability changes during heat treatment on the basis of chemical analysis. Polymer Degradation and Stability 89 (1):1-5

Hon DNS Weathering of wood in structural use. In, Blacksburg, Va, USA, 1981. Environmental Degradation of Engineering in Aggressive Environments, Proceedings of 2nd International Conference on Environmental Degradation of Engineering Materials. Va Polytech Inst, Lab for the Study of Environ Degrad of Eng Mater, pp 519-529, 518

Hon DNS (1984) ESCA study of oxidized wood surfaces. Journal of Applied Polymer Science 29 (9):2777-2784

Hon DNS Wetahering reactions of lignocellulose materials. In, 1985. Polymer 85: An International Symposium on Characterization and Analysis of Polymers - Preprints. Royal Australian Chemical Inst, Polymer Div, p 373

Hon DNS, Chang S-T (1984) Surface degradation of wood by ultraviolet light. Journal of polymer science Part A-1, Polymer chemistry 22 (9):2227-2241

Hon DNS, Feist WC (1986) Weathering characteristics of hardwood surfaces. Wood Science and Technology 20 (2):169-183

Hon DNS, Ifju G (1978) Measuring penetration of light into wood by detection of photo-induced free radicals. Wood Sci 11 (2):118-127

Hon DNS, Minemura N (1991) Color and discoloration. Wood and Cellulosic Chemistry. New York

Horn BA, Qiu J, Owen NL, Feist WC (1992) FT-IR studies of weathering effects in Western red cedar and Southern pine. Chemical Modification of Lignocellulosics

Kalnins MA, Feist WC (1993) Increase in wettability of wood with weathering. Forest Products Journal 43 (2):55

Kang H-Y, Park S-J, Kim Y-S (2002) Moisture sorption and ultrasonic velocity of artificially weathered spruce. Mokchae Konghak 30 (1):18-24

Kataoka Y, Kiguchi M (2001) Depth profiling of photo-induced degradation in wood by FT-IR microspectroscopy. Journal of Wood Science 47 (4):325-327

Kishino M, Nakano T (2004a) Artificial weathering of tropical woods. Part 1: Changes in wettability. Holzforschung 58 (5):552-557

Kishino M, Nakano T (2004b) Artificial weathering of tropical woods. Part 2: Color change. Holzforschung 58 (5):558-565

Kocaefe D, Poncsak S, Boluk Y (2008a) Effect of thermal treatment on the chemical composition and mechanical properties of birch and aspen. BioResources 3 (2):517-537

Kocaefe D, Poncsak S, Dore G, Younsi R (2008b) Effect of heat treatment on the wettability of white ash and soft maple by water. Einfluss der Wa?rmebehandlung auf die Benetzbarkeit von Weißesche und Rot-Ahorn mit Wasser 66 (5):355-361 
Kocaefe D, Shi JL, Yang DQ, Bouazara M (2008c) Mechanical properties, dimensional stability, and mold resistance of heat-treated jack pine and aspen. Forest Products Journal 58 (6):88-93

Li XJ, Cai ZY, Mou QY, Wu YQ, Liu Y (2011) Effects of heat treatment on some physical properties of Douglas fir (Pseudotsuga menziesii) wood. vol 197-198. Guilin

Mburu F, Dumarçay S, Huber F, Petrissans M, Gérardin P (2007) Evaluation of thermally modified Grevillea robusta heartwood as an alternative to shortage of wood resource in Kenya: Characterisation of physicochemical properties and improvement of bio-resistance. Bioresource Technology 98 (18):34783486. doi:10.1016/j.biortech.2006.11.006

Miniutti VP (1964) Microscale changes in cell structure at softwood surfaces during weathering. Forest Prod J 14 (12):571-576

Miniutti VP (1967) Microscopic observations of ultraviolet irradiated and weathered softwood surfaces and clear coatings. US Forest Service Research Paper FPL 74:1-32

Miniutti VP (1973) contraction in softwood surfaces during ultraviolet irradiation and weathering. J Paint Technol 45 (577):27-34

Nelson ML, O'Connor RT (1964) Relation of certain infrared bands to cellulose crystallinity and crystal lattice type. Part II. A new infrared ratio for estimation of crystallinity in cellulose I and II. J Appl Polym Sci 8:13251341

Nguyen T, Johns WE (1979) The effects of aging and extraction on the surface free energy of Douglas fir and redwood. Wood Science and Technology 13 (1):29-40

Nuopponen M, Wikberg H, Vuorinen T, Maunu SL, Jämsä S, Viitaniemi P (2004) Heat-treated softwood exposed to weathering. Journal of Applied Polymer Science 91 (4):2128-2134. doi:10.1002/app.13351

Paajanen LM (1994) Structural changes in primed Scots pine and Norway spruce during weathering. Materiaux et constructions 27 (168):237-244

Pandey KK (1999) A Study of Chemical Structure of Soft and Hardwood and Wood Polymers by FTIR Spectroscopy. Journal of Applied Polymer Science 71 (12):1969-1975

Park BS, Furuno T, Uehara T (1996) Histochemical changes of wood surfaces irradiated with ultraviolet light. Mokuzai Gakkaishi/Journal of the Japan Wood Research Society 42 (1):1-9

Patton TC (1970) Simplified review of adhesion theory based on surface energetics. Tappi 53 (3):421-429

Pavlo B, Niemz P (2003) Effect of temperature on color and strength of spruce wood. Holzforschung 12:539-546

Pétrissans M, Gérardin P, El Bakali I, Serraj M (2003) Wettability of heat-treated wood. Holzforschung 57 (3):301307

Salmén L, Possler H, Stevanic JS, Stanzl-Tschegg SE (2008) Analysis of thermally treated wood samples using dynamic FT-IR-spectroscopy. Holzforschung 62 (6):676-678. doi:10.1515/hf.2008.113

Shi Q, Bao FC, Lu JX, Jiang JH (2011) Effect of heat treatment temperature on the color of okan wood. vol 214. Sanya

Skaar C (1984) Wood-water relationships. Chemistry of Solid Wood Adv Chem 207:127-172

Stamm AJ (1964) Selective adsorption from solution. Wood and Cellulose Science:175-185

Stamm AJ, Loughborough WK (1942) Variation in shrinking and swelling of wood. Trans Amer Soc Mech Eng 64:379-386

Sumi Y, Hale RR, Meyer JA, Leopold AB, Ranby BG (1964) Accessibility of wood and wood carbohydrates measured with tritiated water. Tappi J 47 (10):621-624

Temiz A, Terziev N, Eikenes M, Hafren J (2007) Effect of accelerated weathering on surface chemistry of modified wood. Applied Surface Science 253 (12):5355-5362

Tolvaj L, Faix O (1995) Artificial ageing of wood monitored by DRIFT spectroscopy and CIE L*a*b* color measurements. Holzforschung 49 (5):397-404

Tumen I, Aydemir D, Gunduz G, Uner B, Cetin H (2010) Changes in the chemical structure of thermally treated wood. BioResources 5 (3):1936-1944

Wang S, Zhang Y, Xing C (2007) Effect of drying method on the surface wettability of wood strands. Einfluss des Trocknungsverfahrens auf die Oberflächenbenetzbarkeit von OSB-spänen 65 (6):437-442

Wang SY, Lin SJ (1991) The effect of outdoor environmental exposure on the main component of woods. Mokuzai Gakkaishi 37 (10):954-963

Weiland JJ, Guyonnet R (2003) Study of chemical modifications and fungi degradation of thermally modified wood using DRIFT spectroscopy. Holz als Roh - und Werkstoff 61 (3):216-220

Windeisen E, Strobel C, Wegener G (2007) Chemical changes during the production of thermo-treated beech wood. Wood Science and Technology 41 (6):523-536 


\section{Figure captions}

Fig. 1 Dynamic contact angle of heat-treated wood after artificial weathering for different times: (a) jack pine, (b) aspen, (c) birch

Fig. 2 Comparison of initial contact angle of heat-treated and untreated wood as a function of artifictial weathering time for three specimens

Fig. 3 SEM images ( $\times 2500)$ on transverse surface of specimens before and after $1512 \mathrm{~h}$ of artificial weathering: (a) untreated jack pine before weathering; (b) heat-treated jack pine before weathering; (c) heat-treated jack pine after weathering; (d) untreated aspen before weathering; (e) heat-treated aspen before weathering; (f) heat-treated aspen after weathering; (g) untreated birch before weathering; (h) heat-treated birch before weathering; (i) heat-treated birch after weathering

Fig. 4 Relationship between maximum damage depth and wettability of three heat-treated species before $(0 \mathrm{~h})$ and after artificial weathering for $72 \mathrm{~h}, 672 \mathrm{~h}$, and $1512 \mathrm{~h}$

Fig. 5 FTIR spectra of heat-treated and untreated samples before artificial weathering

Fig. 6 FTIR spectra of heat-treated wood during artificial weathering: (a) jack pine, (b) aspen, (c) birch

Fig. 7 Evolution of the lignin loss as a function of weathering time

Fig. 8 Intensity ratios of bands at $1370 \mathrm{~cm}^{-1}$ (Total Crystallinity Index) to band at $2900 \mathrm{~cm}^{-1}$ in FTIR spectra before (0h) and after artificial weathering for $72 \mathrm{~h}$ and $1512 \mathrm{~h}$

Fig. 9 Relationship between crystallinity $\left(\mathrm{H}_{1370} / \mathrm{H}_{2900}\right)$ and contact angle of heat-treated wood surface

Fig. 10 Intensity ratios of bands at (a) $\left.1740\left(\mathrm{C}=\mathrm{O} / \mathrm{CH}_{2}\right)\right)$ and (b) $3500\left(\mathrm{OH} / \mathrm{CH}_{2}\right.$ ratio) to band at $2900 \mathrm{~cm}^{-1}$ in FTIR spectra before (0h) and after artificial weathering for $72 \mathrm{~h}$ and $1512 \mathrm{~h}$

Fig. 11 Effect of Intensity ratios of bands at $3500\left(\mathrm{OH} / \mathrm{CH}_{2}\right.$ ratio) to band at $2900 \mathrm{~cm}^{-1}$ in FTIR spectra on initial contact angles of three heat-treated woods 
Table 1 Conditions of heat treatment

\begin{tabular}{cccccc}
\hline Latin name & $\begin{array}{c}\text { English } \\
\text { name }\end{array}$ & $\begin{array}{c}\text { Temp. } \\
\left({ }^{\circ} \mathrm{C}\right)\end{array}$ & $\begin{array}{c}\text { Heating Rate } \\
\left({ }^{\circ} \mathrm{C} / \mathrm{h}\right)\end{array}$ & $\begin{array}{c}\text { Holding Time } \\
(\mathrm{h})\end{array}$ & Humidity \\
\hline Pinus banksiana & Jack pine & 210 & 15 & 1 & Yes \\
Populus tremuloides & Aspen & 210 & 15 & 1 & Yes \\
Betule papyrifera & White birch & 215 & 15 & 1 & Yes \\
\hline
\end{tabular}


Table 2 Total wetting time for complete surface wetting by water for three wood species before and after $1512 \mathrm{~h}$ of artificial weathering

\begin{tabular}{ccccc}
\hline Species & $\begin{array}{c}\text { Heat } \\
\text { treatment }\end{array}$ & $\begin{array}{c}\text { Weathering } \\
\text { time (h) }\end{array}$ & $\begin{array}{c}\text { Total wetting } \\
\text { time (s) }\end{array}$ & Stand Error \\
\hline Jack pine & Heat-treated & 0 & 3003.73 & 10.87 \\
& & 1512 & 0.42 & 0.10 \\
Jack pine & Untreated & 0 & 1875.67 & 31.88 \\
& & 1512 & 3.39 & 0.39 \\
Aspen & Heat-treated & 0 & 1730.27 & 503.10 \\
& & 1512 & 0.30 & 0.11 \\
Aspen & Untreated & 0 & 235.43 & 17.78 \\
& & 1512 & 0.51 & 0.20 \\
Birch & Heat-treated & 0 & 2076.61 & 192.28 \\
& & 1512 & 0.30 & 0.07 \\
\multirow{2}{*}{ Birch } & Untreated & 0 & 601.41 & 51.31 \\
& & 1512 & 0.37 & 0.08 \\
\hline
\end{tabular}


Table 3 Characteristic bands of IR absorption spectra in wood

\begin{tabular}{|c|c|c|c|}
\hline $\begin{array}{l}\text { Wavenumber } \\
\left(\mathrm{cm}^{-1}\right)\end{array}$ & Functional Group & Assignment & References \\
\hline $3500-3420$ & $-\mathrm{OH}$ & $\begin{array}{l}\text { Present in water and three wood polymer } \\
\text { components }\end{array}$ & $\begin{array}{l}\text { (Kocaefe et al. 2008a; } \\
\text { Kishino and Nakano 2004a; } \\
\text { Tolvaj and Faix 1995) }\end{array}$ \\
\hline 2900 & $\mathrm{C}-\mathrm{H},-\mathrm{CH}_{2-}$ & $\begin{array}{l}\text { Stretching in methyl and methylene group, } \\
\text { Hydrocarbon chains }\end{array}$ & $\begin{array}{l}\text { (Tolvaj and Faix 1995; } \\
\text { Kishino and Nakano 2004a) }\end{array}$ \\
\hline $1740-1736$ & $-\mathrm{COOH}(\mathrm{C}=\mathrm{O})$ & $\begin{array}{l}\text { Stretching of acetyl or carboxylic acid } \\
\text { (hemicelluloses +lignin), }\end{array}$ & $\begin{array}{l}\text { (Colom et al. 2003; Tolvaj } \\
\text { and Faix 1995) }\end{array}$ \\
\hline 1600 & $\mathrm{C}=\mathrm{C}$ & Aromatic ring (lignin) & (Temiz et al. 2007) \\
\hline 1510 & $\mathrm{C}=\mathrm{C}$ & $\begin{array}{l}\text { Aromatic ring (lignin), stronger } \\
\text { guaiacyl element than syringyl }\end{array}$ & $\begin{array}{l}\text { (Colom et al. 2003; Temiz et } \\
\text { al. 2007) }\end{array}$ \\
\hline 1465 & $\mathrm{C}-\mathrm{H}$ & Asymmetric bending in $\mathrm{CH}_{3}$ (lignin) & (Colom et al. 2003) \\
\hline 1267 & $\mathrm{CO}$ & $\begin{array}{l}\text { Guaiacyl ring breathing with CO- } \\
\text { stretching (lignin and hemicelluloses) }\end{array}$ & (Temiz et al. 2007) \\
\hline 1103 & $\mathrm{C}-\mathrm{H}$ & Guaiacyl and syringyl (lignin) & (Pandey 1999) \\
\hline 1030 & $\mathrm{C}-\mathrm{O}, \mathrm{C}-\mathrm{H}$ & Primary alcohol, guaiacyl(lignin) & (Pandey 1999) \\
\hline 813-809 & & Softwood guaiacyl (lignin) & (Nuopponen et al. 2004) \\
\hline
\end{tabular}



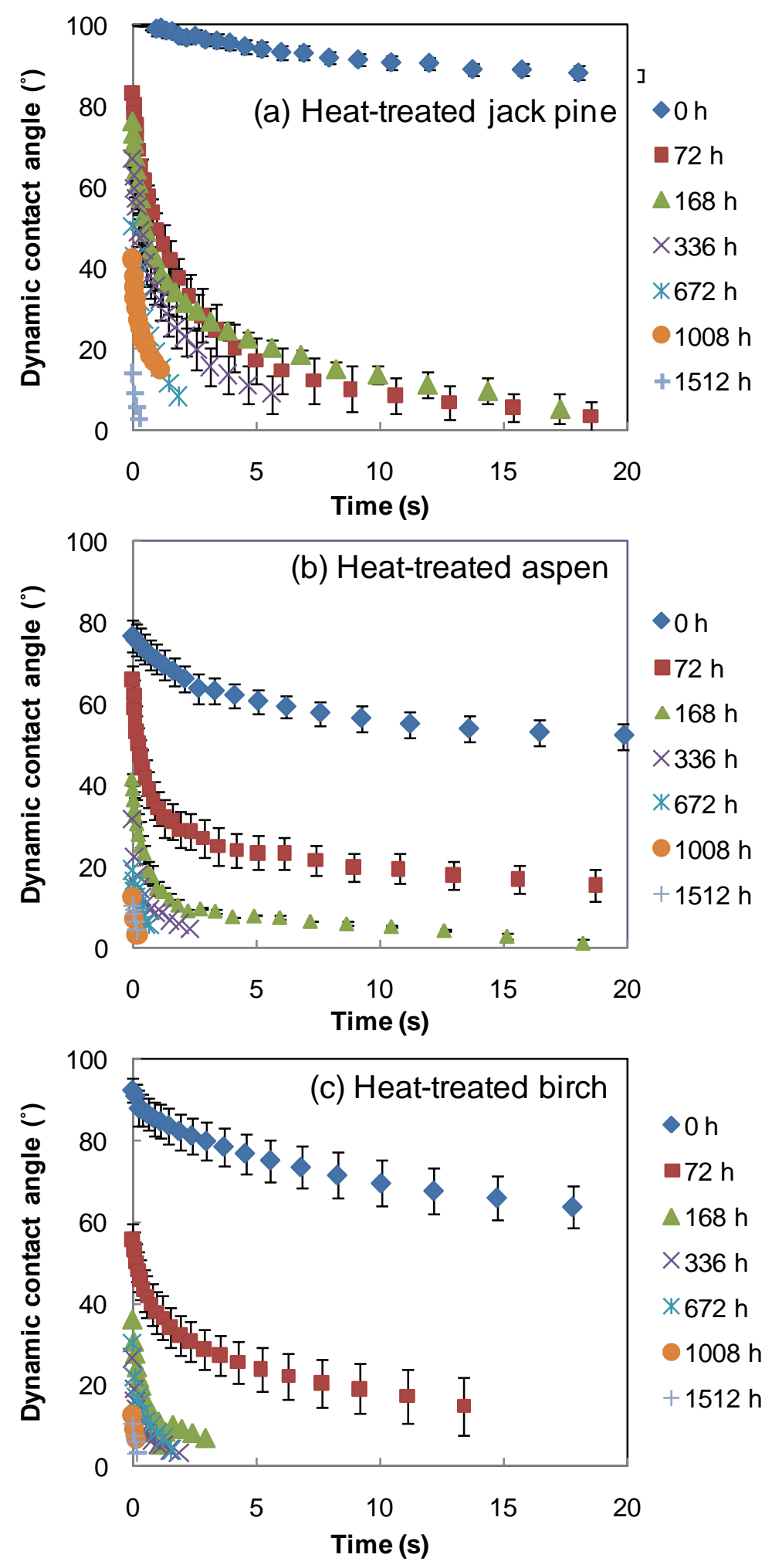

Fig. 1 Dynamic contact angle of heat-treated wood after artificial weathering for different times: (a) jack pine, (b) aspen, (c) birch 

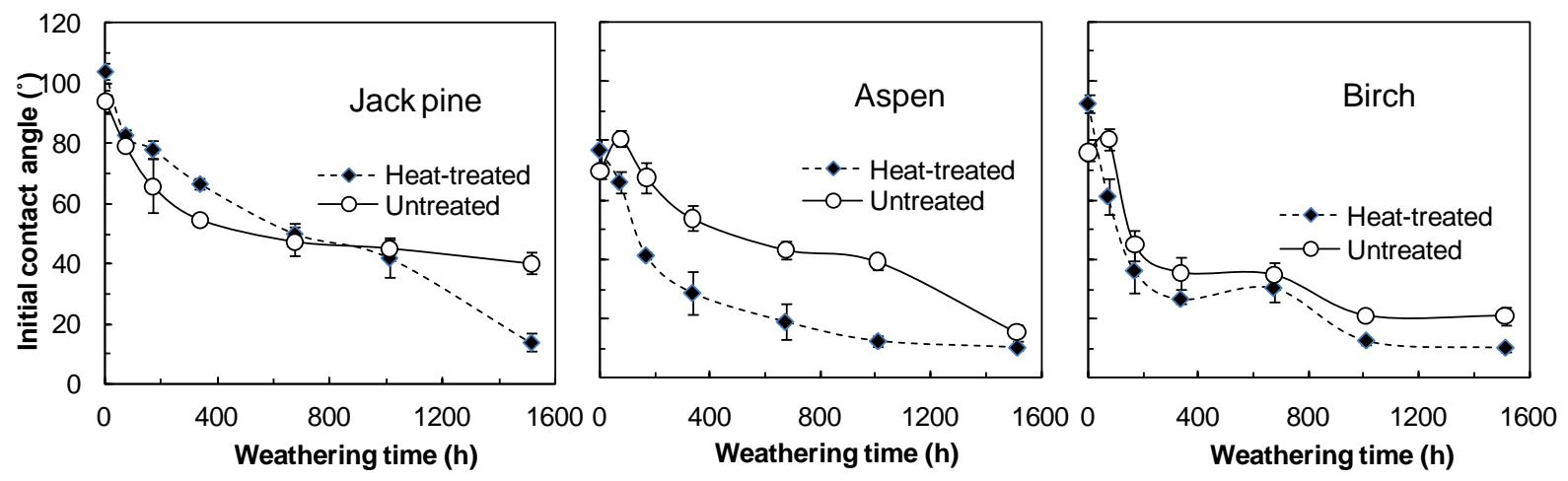

Fig. 2 Comparison of initial contact angle of heat-treated and untreated wood as a function of artifictial weathering time for three specimens 

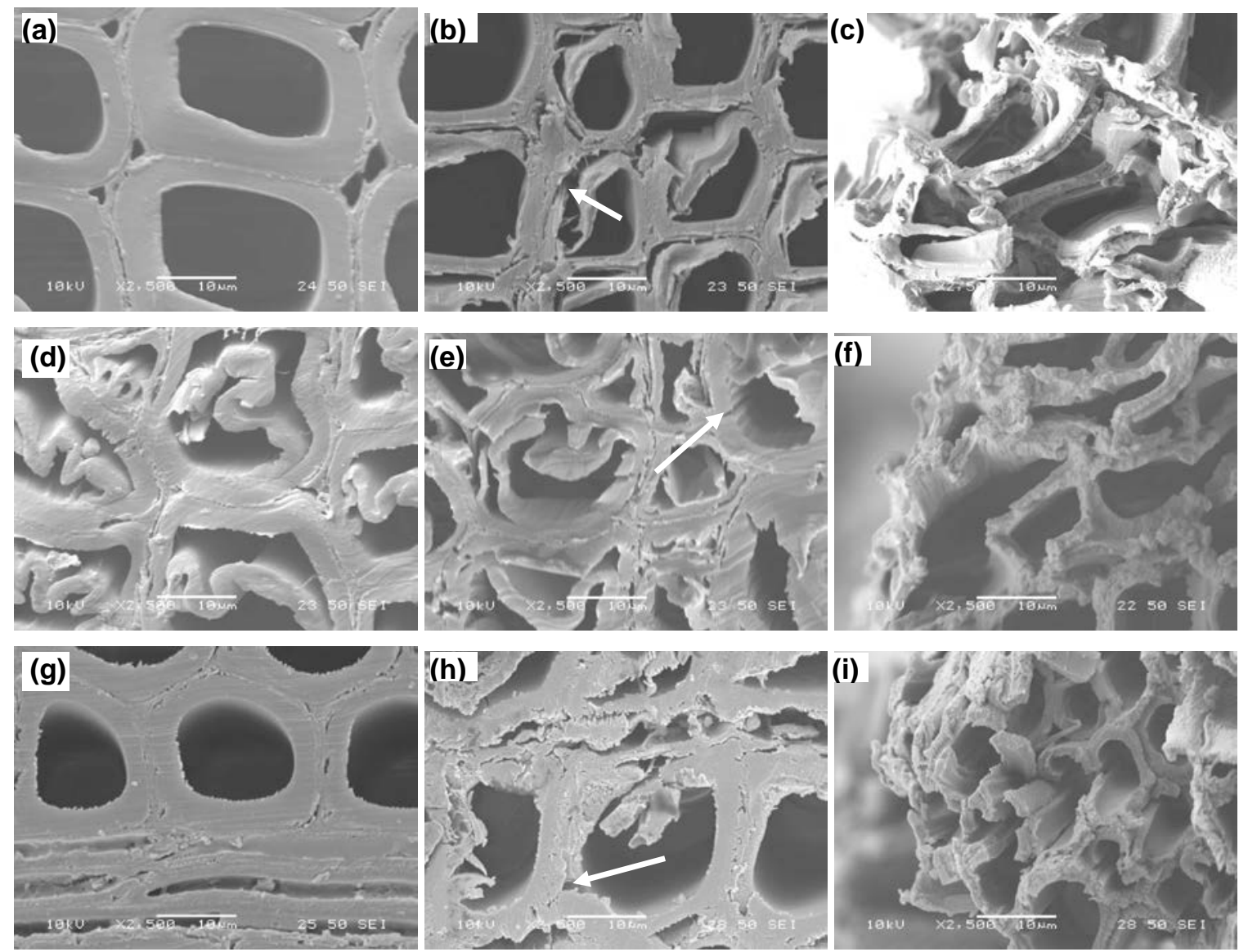

Fig. 3 SEM images ( $\times 2500)$ on transverse surface of specimens before and after $1512 \mathrm{~h}$ of artificial weathering: (a) untreated jack pine before weathering; (b) heat-treated jack pine before weathering; (c) heat-treated jack pine after weathering; (d) untreated aspen before weathering; (e) heat-treated aspen before weathering; (f) heat-treated aspen after weathering; (g) untreated birch before weathering; (h) heat-treated birch before weathering; (i) heat-treated birch after weathering 


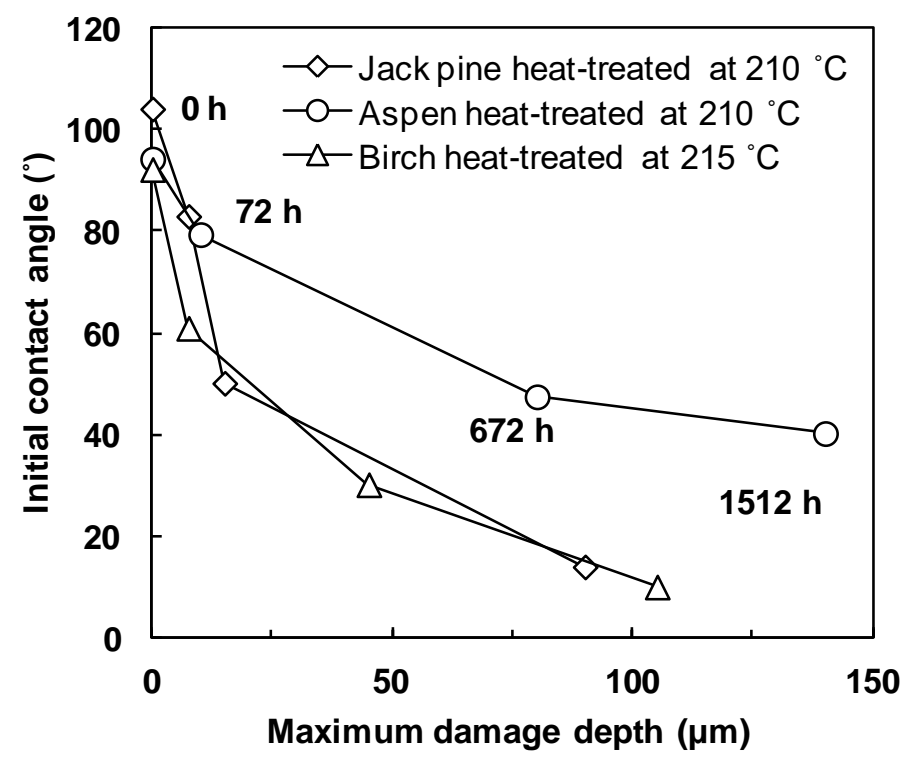

Fig. 4 Relationship between maximum damage depth and wettability of three heat-treated species before ( $0 \mathrm{~h})$ and after artificial weathering for 72 h, 672 h, and 1512 h. 


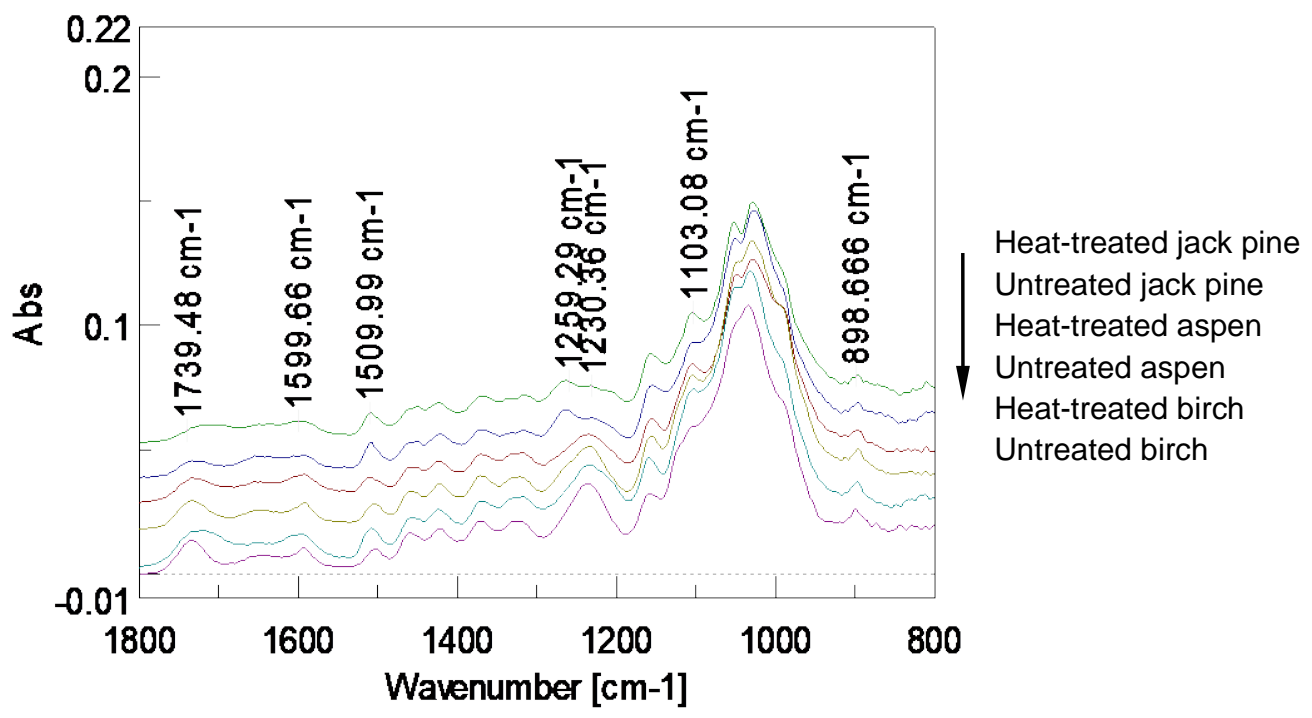

Fig. 5 FTIR spectra of heat-treated and untreated samples before artificial weathering 

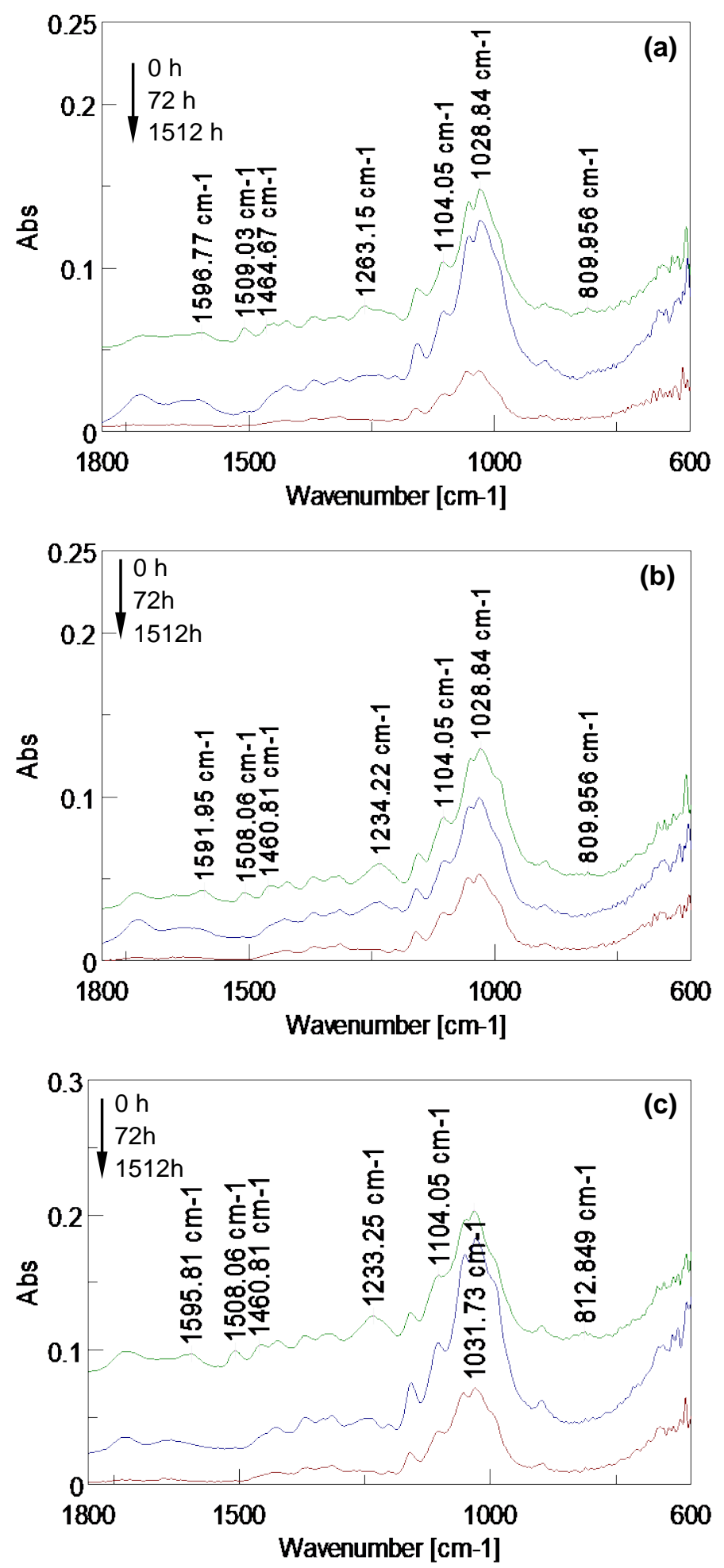

Fig. 6 FTIR spectra of heat-treated wood during artificial weathering: (a) jack pine, (b) aspen, (c) birch 


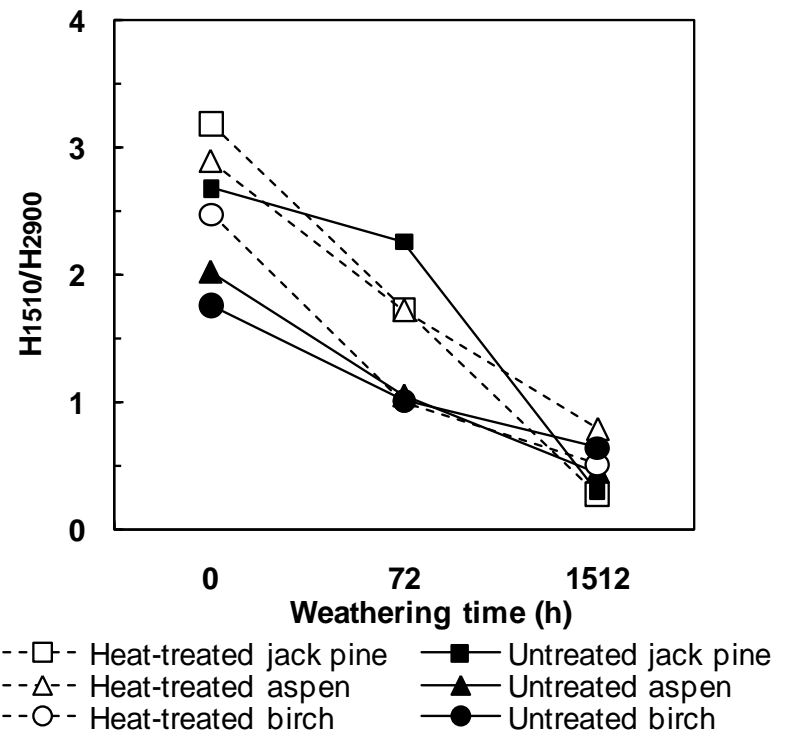

Fig. 7 Evolution of the lignin loss as a function of weathering time 


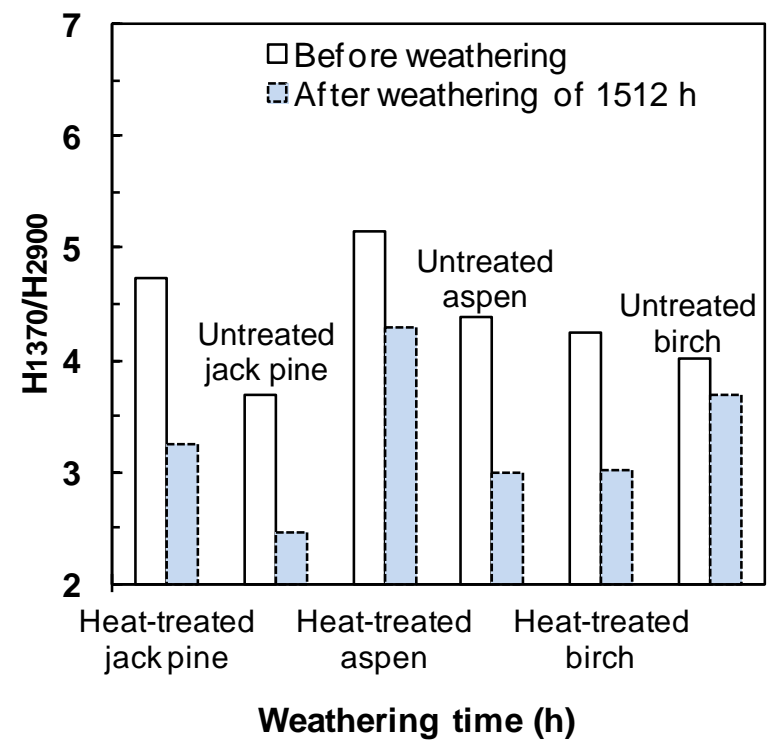

Fig. 8 Intensity ratios of bands at $1370 \mathrm{~cm}^{-1}$ (Total Crystallinity Index) to band at $2900 \mathrm{~cm}^{-1}$ in FTIR spectra before (0h) and after artificial weathering for $72 \mathrm{~h}$ and $1512 \mathrm{~h}$ 


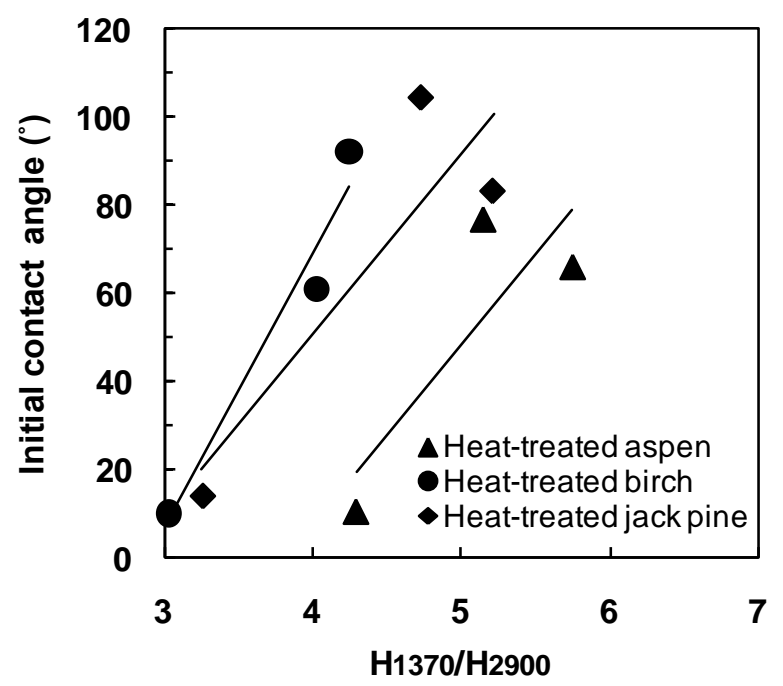

Fig. 9 Relationship between crystallinity $\left(\mathrm{H}_{1370} / \mathrm{H}_{2900}\right)$ and contact angle of heat-treated wood surface 

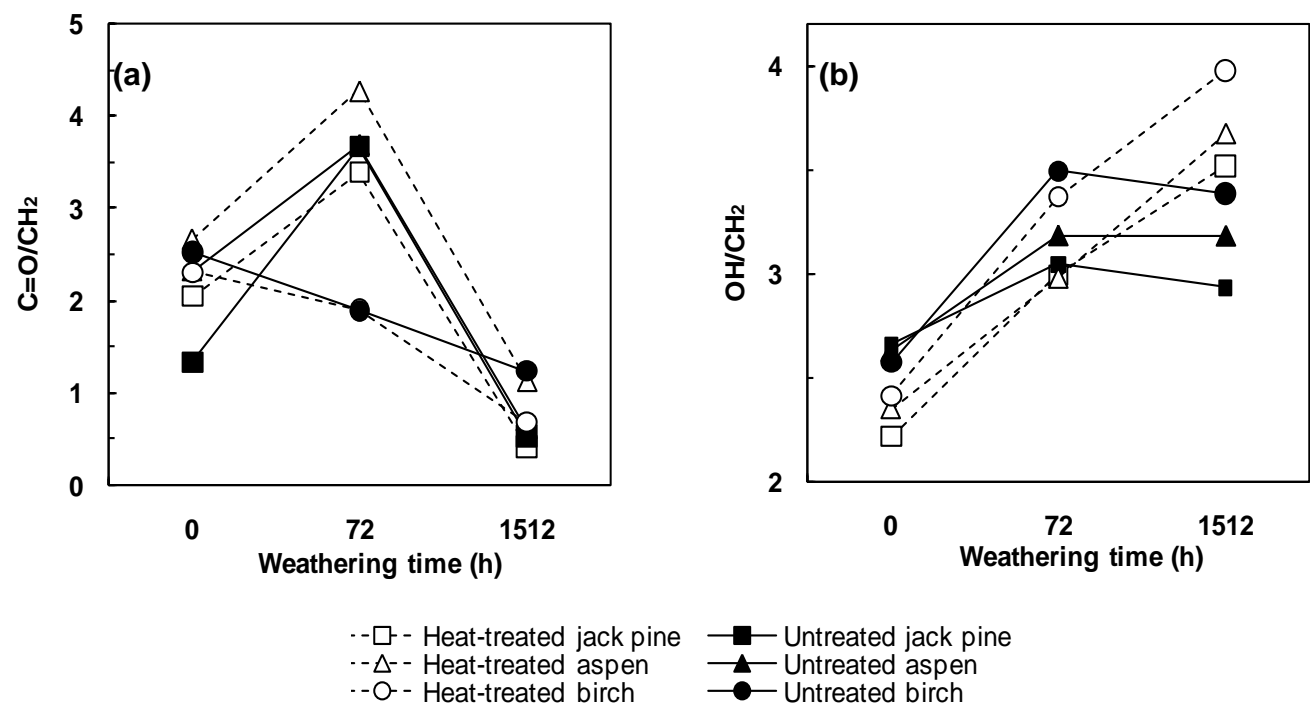

Fig. 10 Intensity ratios of bands at (a) $\left.1740\left(\mathrm{C}=\mathrm{O} / \mathrm{CH}_{2}\right)\right)$ and (b) $3500\left(\mathrm{OH} / \mathrm{CH}_{2}\right.$ ratio) to band at $2900 \mathrm{~cm}^{-1}$ in FTIR spectra before (0h) and after artificial weathering for $72 \mathrm{~h}$ and $1512 \mathrm{~h}$ 


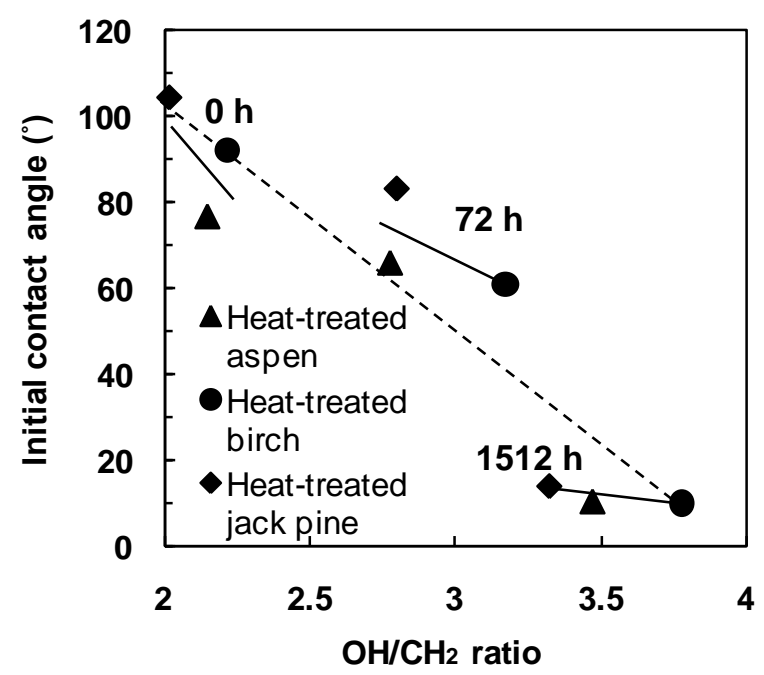

Fig. 11 Effect of Intensity ratios of bands at $3500\left(\mathrm{OH} / \mathrm{CH}_{2}\right.$ ratio) to band at $2900 \mathrm{~cm}^{-1}$ in FTIR spectra on initial contact angles of three heat-treated woods 